\title{
HYPERTENSION FOLLOWING CORONARY ARTERY BYPASS GRAFT
}

\author{
W. Mcilvaine, M. Boulanger, J.G. Malllé, B. Paiement, J. Talllefer and P. Sahab
}

\section{ABSTRACT}

Hypertension following coronary surgery is generally reported at an alarmingly high incidence ( 30 to 75 per cent).

A vigilance program carried out in 1977 at the Montreal Heart Institute disclosed a low incidence of 3.5 per cent in 200 consecutive unselected cases. A similar program in 1980 based on 160 cases showed an incidence of 23.7 per cent. This highly significant difference is found to be related to the differences in anaesthetic management which have occurred since 1977 when anaesthesia was primarily morphine 1.0 to $1.5 \mathrm{mg} \cdot \mathrm{kg}^{-1}$ supplemented as needed with low dose halogenated agents and vasodilation therapy.

In 1980, only one of the authors (J.T.) still uses this technique. The incidence of hypertension in 40 of his patients was 2.5 per cent. The others use low dose fentanyl ( 7.5 to $10 \mu \mathrm{g} \cdot \mathrm{kg}^{-1}$ ) supplemented as needed with halogenated agents and vasodilating therapy; the incidence of hypertension in 160 cases was 23.7 per cent.

Would these results be the same with an anaesthetic technique comparing both drugs at equipotent doses? A prospective clinical study is addressing this question.

KEY WORDS: COMPLICATIONS, hypertension, coronary artery bypass graft.

HYPERTENSION FOLLOWING coronary artery bypass graft $(\mathrm{CABG})$ surgery has been a subject of concern since 1972 . $^{1}$ The incidence is variously reported between 30 and 75 per cent. ${ }^{1-4}$ The possible influence of the anaesthetic agents used on the genesis of this hypertensive syndrome has not been systematically investigated.

The purpose of this study was threefold. First, we sought to determine the incidence of hypertension in the first six hours after CABG at our institution and to compare it to that found in a similar vigilance program in 1977.

From the Department of Anaesthesia, Montreal Heart Institute and the Department of Anaesthesia of the University of Montreal Medical School, Montreal, Quebec, Canada.

W. McIlvaine, M.D., Resident in Anaesthesiology, rotating from McGill University, Department of Anaesthesia; M. Boulanger, M.D., Professor and Chairman, Department of Anaesthesia, University of Montreal, and Staff Anaesthesiologist, Montreal Heart Institute; J.G. Maille, M.D., Chief Anaesthesiologist, Montreal Heart Institute, Associate Professor, Montreal University; B. Paiement and J. Taillefer, M.D., Staff Anaesthesiologists, Montreal Heart Institute, Associate Professors, Montreal University; P. Sahab, M.D., Staff Anaesthesiologist, Montreal Heart Institute.

Address correspondence to: Dr. M. Boulanger, Montreal Heart Institute, 5000 East, Belanger Street, Montreal, Quebec, H1T 1C8, Canada.

Can. Anaesth. Soc. J., vol. 29, no. 3, May 1982
Secondly, we sought to analyze the influence of the various anaesthetic techniques used in 1980 and in 1977.

Thirdly, we wanted to examine the effect of intravenous narcotic analgesia after the completion of bypass on the incidence of hypertension.

For the purpose of this paper, hypertension is defined as a systolic pressure greater than 160 $\mathrm{mmHg}(21.3 \mathrm{kPa})$ and $/$ or a diastolic pressure greater than $100 \mathrm{mmHg}(13.3 \mathrm{kPa})$ which occurs within six hours after operation and persists after sedation, analgesia, and the elimination of obvious causes.

\section{Methods}

As in 1977,200 patients presenting for coronary artery bypass graft surgery were studied. Patients with simultaneous valve replacement or aneurysmectomy were excluded.

All patients were visited before operation and assessed according to the method discussed in a recent article from this institution. ${ }^{5}$ All medications excluding nitrates were stopped at 22:00 of the evening before operation. Each patient received a standard premedication of either pentobarbitone $\left(2 \mathrm{mg} \cdot \mathrm{kg}^{-1}\right)$ or morphine sulfate (0.1 $\mathrm{mg} \cdot \mathrm{kg}^{-1}$ ). 
TABLE I

ANAEsthetic Techniques

\begin{tabular}{|c|c|c|c|c|c|}
\hline & A & $\mathbf{B}$ & C & $\mathbf{D}$ & $\mathbf{E}$ \\
\hline $\begin{array}{l}\text { Diazepam }\left(0.3 \mathrm{mg} \cdot \mathrm{kg}^{-1}\right) \\
\text { Narcotics }\end{array}$ & $\begin{array}{c}+ \\
\text { Morphine } \\
1.5 \mu \mathrm{kgg}^{-1}\end{array}$ & $\begin{array}{c}+ \\
\text { Fentanyl } \\
7 \mathrm{\mu g} \cdot \mathrm{kg}^{-1}\end{array}$ & $\begin{array}{c}+ \\
\text { Fentanyl } \\
8.6 \mu \mathrm{g} \cdot \mathrm{kg}^{-1}\end{array}$ & $\begin{array}{c}+ \\
\text { Fentanyl } \\
10 \mu \mathrm{g} \cdot \mathrm{kg}^{-1}\end{array}$ & $\begin{array}{c}+ \\
\text { Fentanyl } \\
9.5 \mu \mathrm{g} \cdot \mathrm{kg}^{-1}\end{array}$ \\
\hline $\mathrm{N}_{2} \mathrm{O} / \mathrm{O}_{2}(0.4)$ & + & + & + & + & + \\
\hline $\begin{array}{l}\text { Halogenated agentst } \\
\text { Pre-Bypass (per cent) } \\
\text { Post-Bypass (per cent) }\end{array}$ & $\begin{array}{r}20 \\
0\end{array}$ & $\begin{array}{r}100 \\
35\end{array}$ & $\begin{array}{r}100 \\
20\end{array}$ & $\begin{array}{r}75 \\
0\end{array}$ & $\begin{array}{l}90 \\
30\end{array}$ \\
\hline $\begin{array}{l}\text { Vasodilators } \\
\text { Pre-Bypass (per cent) } \\
\text { Post-Bypass (per cent) }\end{array}$ & $\begin{array}{l}80 \\
20\end{array}$ & $\begin{array}{l}85 \\
20\end{array}$ & $\begin{array}{l}70 \\
10\end{array}$ & $\begin{array}{l}65 \\
25 \\
\end{array}$ & $\begin{array}{l}60 \\
30\end{array}$ \\
\hline
\end{tabular}

$\dagger$ Numbers indicate the percentage of cases where halogenated agents and vasodilator therapy were used by each anaesthesist.

Upon arrival in the operating room, peripheral venous and arterial catheterizations were performed after electrocardiograph leads for $\mathrm{CM}_{5}$ were attached. A \#7 French Swan-Ganz catheter was inserted in the right internal jugular vein using the Boulanger technique ${ }^{6}$ in each patient.

After a standard pattem of induction using diazepam $\left(0.3 \mathrm{mg} \cdot \mathrm{kg}^{-1}\right)$, pancuronium $(0.1$ $\left.\mathrm{mg} \cdot \mathrm{kg}^{-1}\right)$ the trachea was intubated following ventilation with pure oxygen by face mask.

Each anaesthetist then followed his own anaesthetic management technique as described in Table I.

Note that anaesthetist A used morphine 1.5 $\mathrm{mg} \cdot \mathrm{kg}^{-1}$ as a main agent, adding volatile agents occasionally and vasodilators frequently during the pre-bypass period.

Anaesthetists $B$ and $C$ relied primarily on volatile agents, completing with low dose fentanyl, whereas anaesthetists $\mathrm{D}$ and $\mathrm{E}$ use slightly higher doses of fentanyl completing with volatile agents when felt necessary (Table I).

For maintenance, ventilation was controlled with an Ohio Anaesthesia Ventilator Fluidic model using a circle circuit without carbon dioxide absorption. Fresh gas flows of five litres (nitrous oxide 3 , oxygen 2) were used and ventilation was adjusted to maintain normocarbia. Catheterizations of bladder and left external jugular vein were followed by insertion of a gastric tube and temperature probes in the nasopharynx and rectum.

Cardiopulmonary bypass with nonpulsatile flow, bubble oxygenation and a clear prime of 2/3 lactated Ringer's solution and 1/3 five per cent glucose in distilled water was established after systemic heparinization. Haemodilution to an haematocrit of 22 to 25 per cent preceded hypothermia to 25 degrees $C$. Cold cardioplegia solution was administered under pressure to reduce the intramyocardial temperature to 10 degrees $\mathrm{C}$. The composition of the solution was indentical in 1977 and 1980 (Appendix A). The aortic cross clamp was removed after the distal anastomoses were completed and a side biting clamp on the aorta was used for completion of the proximal anastomoses during rewarning. All pump blood was reinfused to the patients either in the operating room or in the intensive care unit according to their volume status.

In the intensive care unit, patients were ventilated by a Bennet MA-1 with a tidal volume of $12 \mathrm{ml} / \mathrm{kg}$ at ten breaths per minute with an $\mathrm{FIO}_{2}$ of 0.4 and subsequently adjusted according to the arterial gas analysis to maintain normocarbia.

\section{Measurement of Blood Pressure}

Our technique for measuring blood pressure is standard for all nursing personnel. A sphygmomanometer cuff is placed on the cannulated side and is inflated until the arterial trace becomes a flat line on the monitor screen. While slowly deflating the cuff, the nurse observes both the aneroid gauge and the monitor screen. Systolic pressure is that pressure at which the trace first reappears; diastolic pressure is determined when the signal returns to full amplitude.

Patients receive a maximum of three intravenous doses of diazepam $5 \mathrm{mg}$ for sedation and morphine sulfate $5 \mathrm{mg}$ for analgesia while intubated. If hypertension develops which persists after apparent sedation, the patient receives an intravenous infusion of sodium nitroprusside $(250 \mu \mathrm{g} / \mathrm{ml})$. 
RESULTS

In Table II the incidence of immediate post-operative hypertension in 1977 (3.5 per cent) is compared to that occurring in 1980 (23 per cent). This difference is significant $(\mathrm{p}<$ 0.001 ). In Table III, the number of cases of hypertension is tabulated for each anaesthetist: anaesthetist $A$, using morphine $1.5 \mathrm{mg} \cdot \mathrm{kg}^{-1}$ had one case of hypertension in 40 patients ( 2.5 per cent) whereas anaesthetists B, C, D and E had 38 hypertensive cases in 160 patients (23.7 per cent). This is highly significant $(p<0.001)$.

Moreover, in Table III, the number of cases of hypertension is compared between those who did and did not receive an analgesic immediately post-pump.

The difference ( 28 vs 18.7 per cent) is not statistically significant ( $p>0.5$ ). Table III also shows that anaesthetist $\mathrm{C}$ reduced his incidence of hypertension from $9 / 20$ to $1 / 20$ by using narcotics following extra-corporeal circulation.

There were no significant differences between the patients of B, C, D and E and those of $A$ in terms of height, weight, age, sex, number of grafts, intraoperative fluid balance, prevalence of beta-blocker usage, phentolamine dosage, and rectal temperature on arrival in the intensive care unit or during the hypertensive episode.

To elucidate the evolution of postoperative hypertension, we followed the patients who developed hypertension after the termination of bypass while still in the operating room. The results are shown in Table IV. We found 38 patients who became hypertensive in the operating room. Despite immediate treatment, 16 of them required vasodilator therapy within 8 hours of arrival in the intensive care unit. In the other 62 patients who remained normotensive in the operating room, only 7 developed significant hypertension. This group of 100 patients had not received a prophylactic analgesia post-pump.

TABLE II

INCIDENCE OF POST CABG BYPASS HYPERTENSION

\begin{tabular}{ccr}
\hline \hline Year & Number & \% HTA \\
\hline 1977 & 200 & $3.5 \%$ \\
1980 & $160^{*}$ & $23.7 \%$ \\
\hline
\end{tabular}

*Note: 40 patients of anaesthetist A done with Morphine in 1980 were removed from the 1980 group of 200 .

\section{Discussion}

The characteristics of immediate postoperative hypertension in the coronary artery bypass graft patient have been well described by numerous authors. ${ }^{7,8}$ A relatively common occurrence, the hypertensive episode begins in the period following termination of bypass. Initially the peripheral vascular resistance is low and the cardiac output is high. When the peripheral vascular resistance starts to increase, hypertension may result if left ventricular function is adequate. If not, cardiac failure may occur, as evidenced by a rise in left ventricular enddiastolic pressure. Neither tachycardia nor bradycardia is common in this setting.

This high incidence of hypertension after coronary artery bypass surgery has been related to an increase in sympathetic activity accompanied by a decrease in baroreceptor sensitivity, because this hypertension is not accompanied by reflex bradycardia and/or peripheral vasodilation. ${ }^{2,3,9}$ This increased sympathetic activity has not been conclusively demonstrated by the measurement of plasma levels of catecholamines.

Pratilas $^{2}$ has shown that norepinephrine levels are significantly elevated in the hypertensive patients when compared to non-hypertensive patients one hour after operation. However, four hours after the operation, the plasma levels did not differ between the hypertensive and nonhypertensive patients. As for epinephrine, no difference was demonstrated at any time. It was not possible to differentiate the groups by observing the catecholamine levels. Roberts ${ }^{8}$ has shown an increase in plasma catecholamines in hypertensive and non-hypertensive groups, but this increase is significant only for norepinephrine in the hypertensive group.

Niarchos ${ }^{9}$ has identified two types of hypertensive patients by measuring plasma renin activity: those with increased plasma renin activity and those with normal plasma renin activity. The former group responds positively to angiotensin inhibitor therapy: the latter does not.

Another factor, considered important in the genesis of this syndrome, is the non-pulsatile nature of flow during extra-corporeal circulation. Landymore ${ }^{10}$ studied 20 patients and found an 80 per cent incidence of hypertension in the patients who were perfused with non-pulsatile flow. This hypertension was accompanied by an increased plasma renin activity. The incidence was only 20 per cent without increase in renin 
MCILVAINE, et al:: HYPERTENSION FOLLOWING CORONARY ARTERY BYPASS

TABLE III

Hypertension Post-CABG: Influence of Narcotics Post-Pump

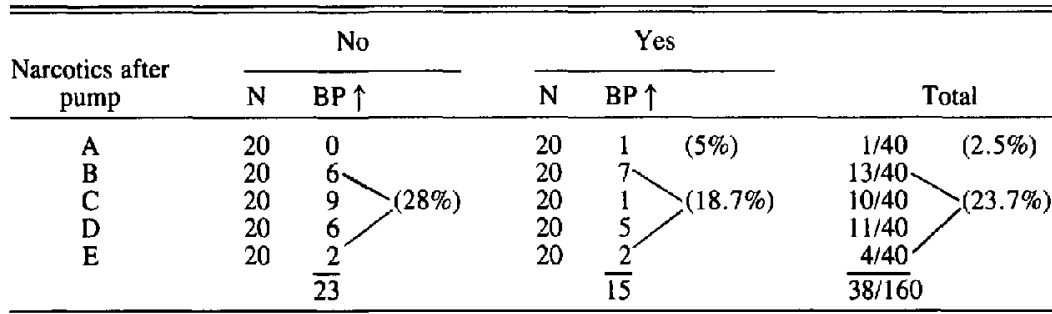

TABLE IV

Evolution According to Level of Blood PresSURE AFTER BYPASS

\begin{tabular}{ccc}
\hline \hline $\begin{array}{c}\text { Blood pressure } \\
\text { after bypass }\end{array}$ & Number & $\begin{array}{c}\text { I.C.U. vasodilator } \\
\text { therapy }\end{array}$ \\
\hline $\begin{array}{c}\uparrow \text { B.P. } \\
\text { normal }\end{array}$ & 38 & $16(42.1 \%)$ \\
\hline
\end{tabular}

activity when pulsatile flow was used. However, these results have not been confirmed by other investigators. ${ }^{11}$

Thus, a definite explanation has not yet been found. Plasma catecholamine levels do not correlate well. Indeed, catecholamine levels bring more confusion than light to this question. For example, Vlashakis injected norepinephrine into normotensive volunteers ${ }^{2}$ and obtained higher plasma levels than those observed in hypertensive patients. However, these volunteers did not develop hypertension. The lack of correlation may mean that the susceptibility is different between volunteers and patients; that the balance between alpha and beta-adrenergic receptor activity may differ from one patient to the other; or that there may be reduced neuronal reuptake and/or clearance of catecholamines in patients compared to volunteers.

One may postulate a possible role for betablockers. If the extra-corporeal circulation markedly reduces the level of beta-blocking activity, a situation of denervation sensitization of the receptor may possibly exist. ${ }^{6}$ Conversely, if beta-blocking activity is still present, alphaagonist receptors may predominate, leading to increased peripheral vascular resistance.

According to Estafanous, ${ }^{12}$ the site of the operation is the source of pressor reflex stimulation originating from the cardiac structures and transmitted through the cardiac sympathetic nerves. He, therefore, recommends stellate ganglion block.

Bachuber and Kampine ${ }^{13}$ have shown recently that halothane anaesthesia can modify the vasomotor reflexes originating from the heart following an acute coronary occlusion in dogs. This supports the hypothesis that anaesthetic management can play a role in the aetiology of this syndrome. Can we not postulate that mechanical receptors in the myocardium are stimulated by manipulation of the coronary arteries during surgery and that the anaesthetic agent may modify the elicited response?

Therefore, the difference between the incidence in 1977 when all cases were done under morphine anesthesia and in 1980 when only 20 per cent of our cases were done using this method, suggests that morphine anesthesia modifies this response and may have a preventive effect on postoperative hypertension, possibly through a vasodilator effect persisting during the immediate postoperative period.

The first question is whether or not there is an association of hypertension with halogenated agents when compared to a pure intravenous technique.

In our study, there was a clear relationship between the anaesthetic agents employed and the incidence of hypertension. There were no hypertensive patients amongst those who received morphine sulphate/nitrous oxide anaesthesia, while the use of halogenated agents and low dose fentanyl was associated with a much greater incidence.

The second question is: what is the incidence of this hypertensive syndrome in patients anaesthetized with high doses of fentanyl (50 to $100 \mu \mathrm{g} \cdot \mathrm{kg}^{-1}$ ) and how does it compare with morphine anaesthesia? Our data cannot supply 
an answer to this question as the two narcotics were not used in equipotent doses. A prospective clinical study is actually underway.

The use of prophylactic narcotic analgesia immediately post-pump has reduced the incidence of hypertension from 28 to 18.7 per cent. However, these results were not statistically significant $(p>0.05$ ) but it may possibly indicate a tendency which could become significant with higher doses. The finding that anaesthetist $\mathrm{C}$ reduced the incidence of hypertension in his patients from $9 / 20$ to $1 / 20$ by using post-pump analgesia is somewhat startling and can hardly be explained with the available data.

However, our data show conclusively that the hypertension which starts in the operating room after the termination of bypass is likely to require intravenous vasodilator therapy in the first eight hours after operation.

Finally, we questioned the incidence of hypertensive episodes in this type of patient presenting for non-cardiac surgery. Therefore we have examined the records of 14 patients who have had coronary artery bypass graft and, some time later, abdominal aortic surgery: no hypertension was observed following CABG, but it occured in eight patients following abdominal aortic surgery. This paroxystic immediate postoperative hypertension is not specific to coronary artery bypass graft surgery. The anaesthetic management of these 14 patients was not studied.

To summarize, we have shown that the incidence of immediate postoperative hypertension is minimal in the coronary bypass graft patients anaesthetized with morphine sulphate at the Montreal Heart Institute. We have demonstrated the incidence of this type of hypertention to be 23 per cent in those patients receiving small dose fentanyl supplemented with halogenated agents. Finally, we have shown that the hypertension which starts in the operating room after the termination of bypass is likely to require intravenous vasodilator therapy in the first eight hours after operation.

\section{Appendix A}

Composition of cardioplegic solution:

\begin{tabular}{|c|c|}
\hline $\begin{array}{l}\mathrm{KCl} \\
\text { Procaine } \\
\text { Mannitol } \\
\text { Bicarbonate }\end{array}$ & $\begin{array}{l}12 \mathrm{mmol} \\
100 \mathrm{mg} \\
12.5 \mathrm{~g} \\
\text { ad } \mathrm{pH} 7.40\end{array}$ \\
\hline
\end{tabular}

\section{REFERENCES}

1. Estafanous, F.G., Tarazi, R.C., Viljoen, J.F. \& EL TAWIL, M.Y. Systemic hypertension following myocardial revascularization. Am. Heart J., 85: 732 (1973)

2. Pratilas, V., Pratila, M.G., Vlachakis, N.D., Owirz, S. \& Dimich, I. Sympathetic nervous system tonicity and post-coronary artery bypass hypertension. Acta Anaesth. Scand., 24: $69(1980)$.

3. Fouad, F.M., Estafanous, F.G., Bravo, E.L., IYER, K.A., MAYDAK, J.H. \& TARAZI, R.C. Possible role of cardioaortic reflexes in postcoronary bypass hypertension. Am.J. Cardiol, , 44: 866 (1979).

4. Hoar, P.F., Hickey, R.F. \& Ullyot, D.J. Systemic hypertension following myocardial revascularization. A method of treatment using epidural anesthesia. J. Thorac. Cardiovasc. Surg., 7I: 859 (1976).

5. Paiement, B., Maille, J.G., Boulanger, M., Taillefer, J., Sahab, P., Pelletier, C. \& DYRDA, I. La visite pré-opératoire en chirurgie cardio-vasculaire. Can. Anaesth. Soc. J., 27 : 584 (1980)

6. AHLQUIST, R.P. Adrenergic receptors and others. Anesthesia Analgesia, 58: 510 (1979).

7. Estafanous, F.G. \& Tarazi, R.C. Systemic arterial hypertension associated with cardiac surgery. Am. J. Cardiol., 46: 685 (1980).

8. Roberts, A.J., Niarchos, A.P., Subramanian, V.A., AbEL, R.M., Herman, S.D., SealEY, J.E., CASE, D.B., WhITE, R.P., JOHNSON, G.A., Laragh, J.H., GaY, W.A., JR. \& OkINAKA, A.J. Systemic hypertension associated with coronary artery bypass surgery. Predisposing factors, hemodynamic characteristics, humoral profile, and treatment. J. Thorac. Cardiovasc. Surg., 74: 846 (1977).

9. Niarchos, A.P. Roberts, A.J., Case, D.B. GAY, W.A., JR. \& LARAGH, J.H. Hemodynamic characteristics of hypertension after coronary bypass surgery and effects of the converting enzyme inhibitor. Am. J. Cardiol., 43: 586 (1979).

10. LANDYMORE, R.W., MURPHY, D.A., KinLEY, C.E., PARrot, J.C., Moffitt, E.A. Longley, W.J. \& QUIRBI, A.A. Does pulsatile flow influence the incidence of postoperative hypertension? Ann. Thorac Surg., 28: 261 (1979).

11. Salerno, T.A., Henderson, M., Keith, F.M. \& ChARRETTE, E.J.P. Hypertension after coronary operation: can it be prevented by pulsatile perfusion? J. Thorac, Cardiovasc. Surg., 81: 396 (1981).

12. Tarazi, R.C. Estafanous, F.G., Founan F.M. Unilateral stellate block in the treatment of hypertension after coronary bypass surgery. Am. J. Cardiol., 42: 1013 (1978)

13. Bachuber, S.R. SEagard, J.L., Bosnjak, Z.J. \& KaMPINE, J.P. The effect of halothane on reflexes elicited by acute coronary artery occlusion of the dog. Anesthesiology, 54:481 (1981). 


\section{RÉsumé}

Des phénomènes hypertensifs paroxystiques ont été rapportés depuis 1972 à la suite de chirurgie coronaire à des incidences entre 30 et 75 pour cent par différents auteurs. En 1977, un programme de vigilance a été mis sur pied pour déterminer l'incidence dans notre propre milieu, programme qui a confirmé nos impressions cliniques d'alors en démontrant un taux de 3.5 pour cent seulement. Le programme d'observation avait porté sur 200 malades.

Trois ans plus tard, en 1980, le même programme de surveillance est appliqué et cette fois on découvre un taux de 23.7 pour cent d'hypertension post-opératoire. A l'analyse, on s'aperçoit que les techniques chirurgicales n'ont pas changé, qu'on emploie la même formule de cardioplégie, que les temps de circulation extracorporelle sont les mêmes de même que l'hypothermie employée. Cependant, on remarque que la technique anesthésique employée s'est modifiée depuis 1977. En effet, alors, on employait l'anesthésie à base de sulfate de morphine de l'ordre de 1.5 à $2 \mathrm{mg} \cdot \mathrm{kg}^{-1}$ avec des suppléments halogénés à l'occasion et des vasodilatateurs peropératoires si nécessaire; en 1980, un seul des cinq anesthésistes continue d'employer cette technique, les autres ayant remplacé la morphine par le fentanyl à petites doses $\left(7-10 \mu \mathrm{g} \cdot \mathrm{kg}^{-1}\right)$ supplées au besoin avec des agents halogénés. Or, si on observe les incidences relatives d'hypertension, on s'aperçoit que celui qui est resté fidèle à la morphine a un cas d'hypertension sur 40 malades alors que tous les autres cas relevés sur 200 malades appartiennent à la clientèle des autres anesthésistes.

Ces observations préliminaires nous permettent de poser la question suivante : Quelles seraient les incidences d'hypertension chez deux groupes de malades se présentant pour chirurgie des coronaires quand un groupe recevrait une anesthésie à base de morphine et l'autre à base de fentanyl à doses équipotentes ? L'investigation est actuellement en cours. 